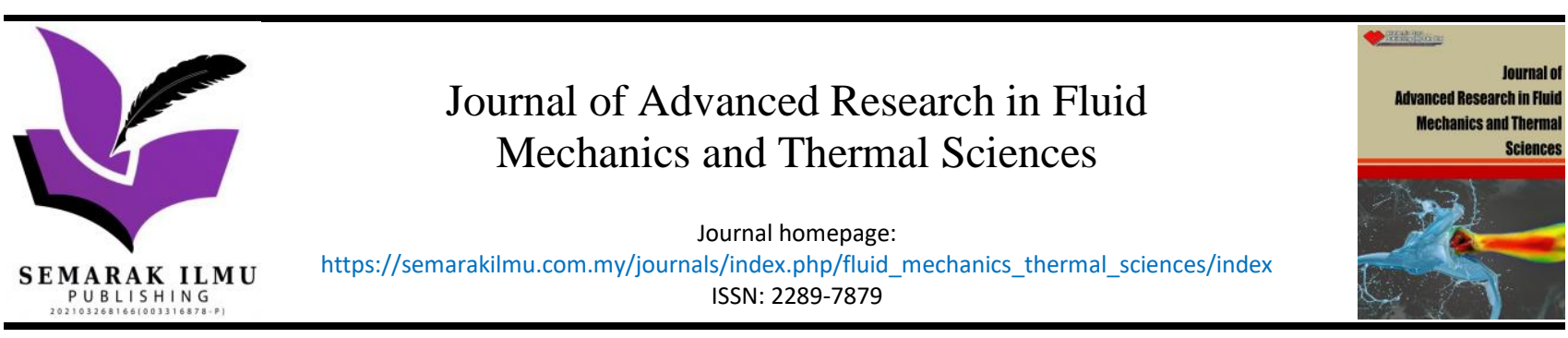

\title{
Analysis Of the Effect of Flow Rate and Speed on Four Blade Tubular Water Bulb-Turbine Efficiency Using Numerical Flow Simulation
}

\author{
Febri Budi Darsono ${ }^{1}$, Rahmad Doni Widodo ${ }^{1}$, Rusiyanto ${ }^{1}$, Akhmad Nurdin $^{2, *}$ \\ Department of Mechanical Engineering, Faculty of Engineering, Universitas Negeri Semarang, Semarang, Central Java, Indonesia \\ Department of Foundry, Politeknik Manufaktur Ceper, Klaten, Central Java, Indonesia
}

\section{ARTICLE INFO}

Article history:

Received 26 September 2021

Received in revised form 18 November 2021

Accepted 22 November 2021

Available online 26 December 2021

\section{Keywords:}

Hydropower; Pico-Hydro; Computational Fluid Dynamic; Propeller; Efficiency

\section{ABSTRACT}

At the smallest scale, hydropower or pico-hydro can be produced by utilizing water flow at the piping system. This paper discusses about the performance of a water bulbturbine in a water piping water system using the Computational Fluid Dynamic (CFD) method. This study aims to analyze the effect of flow rate and speed on the efficiency of water bulb-turbine using Solidworks Flow Simulation 2016. The propeller turbine design used in this study has 4 blades and a blade angle of $20^{\circ}$, and the static bulb using with a ratio of 0.6 to the pipe diameter. The parameter in flow rate applied in this study is between 7 and $13 \mathrm{~L} / \mathrm{s}$ and for speed parameter between 100 and $1700 \mathrm{rpm}$. The final result of this study indicates that the efficiency of the water bulb-turbine is a directly proportional increase of flow rate and the highest efficiency reaches at flow rate $13 \mathrm{~L} / \mathrm{s}$ and $1300 \mathrm{rpm}$.

\section{Introduction}

Based on the nature of renewable, alternative energy has a role replace fossil energy dwindling availability [1]. Located in a tropical climate, alternative energy in Indonesia still has the potential to be developed, such as water energy [2], wind energy [3-5], biogas energy [6, 7], biomass energy [8], photovoltaic [9]. Water energy or hydropower in the smallest scale category producing no more than $5 \mathrm{~kW}$ is called picohydro [10,11]. In its application, hydropower on a picohydro scale can be generated in a water piping system or water tubular on a horizontal flow [1]. Several studies of horizontal flow picohydro applications were experimentally carried out on reference $[1,12,13]$ using propeller turbines, whereas research using numerical simulation methods was carried out on reference [14] using drag-type turbines, and on reference $[11,12]$ using a propeller turbine.

Propeller turbines have several advantages including practical, high performance, and relatively low manufacturing costs [16]. Several previous studies of propeller turbines in piping systems with experimental methods and numerical simulation methods show parameters that affect the performance of the propeller turbine, including bulb ratio [1, 12], number of blades [12, 13] dan blade

\footnotetext{
* Corresponding author.

E-mail address: nurdin@polmanceper.ac.id
}

https://doi.org/10.37934/arfmts.90.2.18 
angle $[1,11]$. Compared to the experimental method, the numerical simulation method on a water turbine is able to show a detailed and accurate flow phenomenon analysis, besides that the numerical simulation method can also support and corroborate the results of the experimental method [10].

A static bulb is placed before the propeller turbine and hereinafter referred to as the bulb turbine to increase the water flow velocity $[18,19]$, thus potentially increasing turbine performance [16]. Several studies on static bulb turbines for the picohydro scale on horizontal flow in piping systems have been carried out in references $[1,11,12]$, from all these studies more complex research has not been carried out on the characteristics of turbine speed $(\mathrm{rpm})$ on turbine performance.

Based on observations from several references, research on static bulb turbines for the picohydro scale on horizontal flow in piping systems has been widely carried out, but more in-depth research about the characteristics of turbine speed (rpm) has not been carried out. This paper aims to investigate about the characteristics of the influence of flowrate and speed (rpm) to the performance of static horizontal bulb turbine flow in piping systems using numerical simulation method.

\section{Methodology}

Design of the inlet and outlet curvature of the propeller turbine used in this study refers to the design in reference $[16,17]$ with a 200 -blade angle as referred to in reference [1], while the turbine tip-hub diameter refers to reference [13] with the diameter ratio bulb to 0.6 inlet pipe diameter refers to reference [15] and the number of blades 4 . Figure 1, Figure 2, and Figure 3 shows the turbine propeller, the assembly turbine propeller with bulb body, and the total assembly rig used in this study.
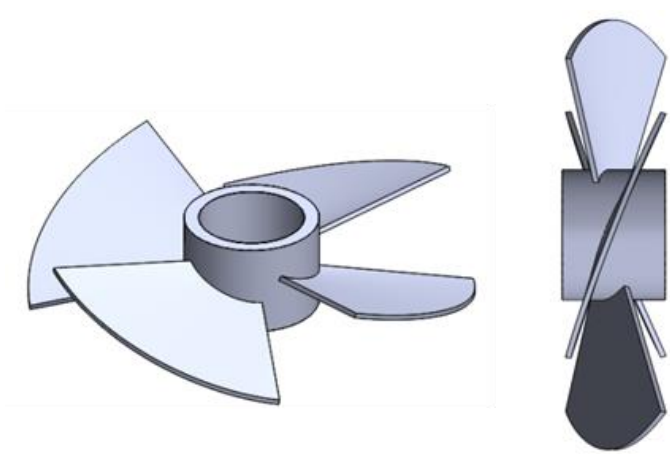

Fig. 1. Four blade propeller design

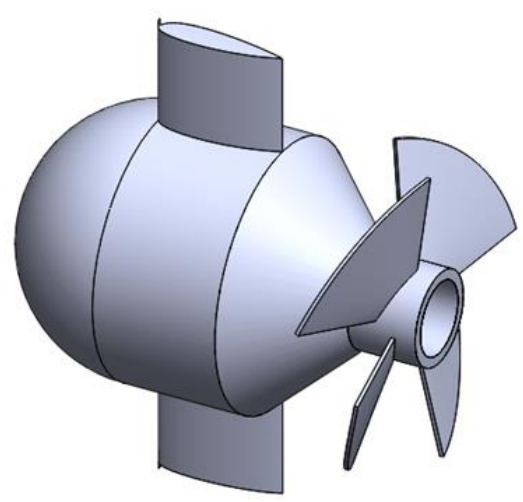

Fig. 2. Assembly propeller turbine with bulb body 


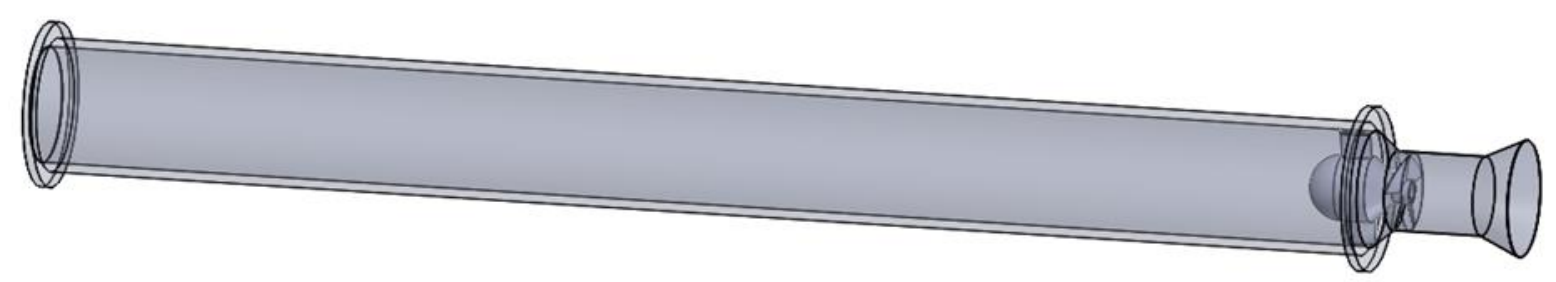

Fig. 3. Total rig assembly

The numerical simulation process in this study uses Solidworks 2016 Flow Simulation software. To obtain accurate simulation results, validation testing is necessary in determining the meshing level [15]. In this study using meshing level 5, referred to reference [15] which has a similar design.

The boundary conditions of numerical simulation in this study are shown Figure 4 and Figure 5. Figure 4 shows the inlet flow parameters between 0.007 to $0.013 \mathrm{~m} 3 / \mathrm{s}$ and on the outlet side using the parameter or $101325 \mathrm{~Pa}$ atmospheric pressure, whereas Figure 5 Shows the parameter regional rotation of the turbine between 100 to 1700 RPM. The object of this simulation lies in the torque value of the turbine in the flow direction $(\mathrm{x})$, with the SG Torque $(\mathrm{X})$ parameter on the turbine.

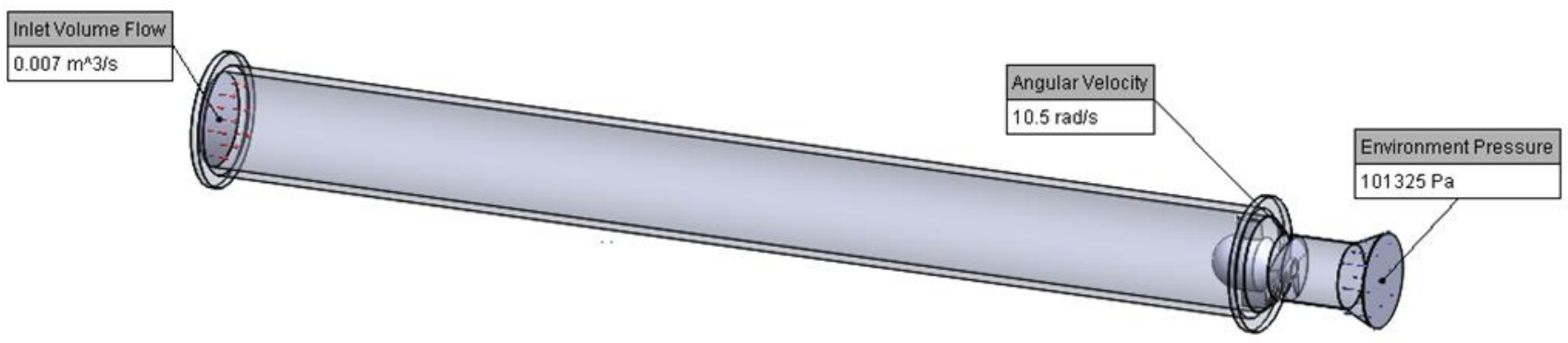

Fig. 4. Boundary condition on rigtest

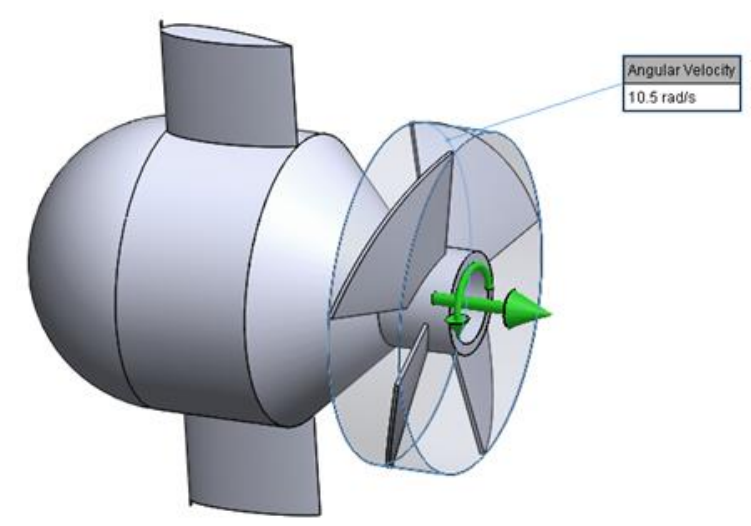

Fig. 5. Boundary condition of rotating region on the turbine

\section{Experimental Result and Discussion}

This study shows the simulation results of propeller turbine performance including torque, power, and efficiency at varying flowrate and speed (rpm). It also shows the velocity contour and the pressure contour on the blade surface. 
Figure 6 shows the relationship between the turbine speed and the torque generated at each flowrate variation, the torque value decreases with increasing turbine rotation, based on the basic power formula [1] the value of torque and speed ( $\mathrm{rpm}$ ) is always inversely proportional, so that the rotation value increases, the torque value will decrease. The figure also shows the same torsion trendline characteristics for each flow variation.

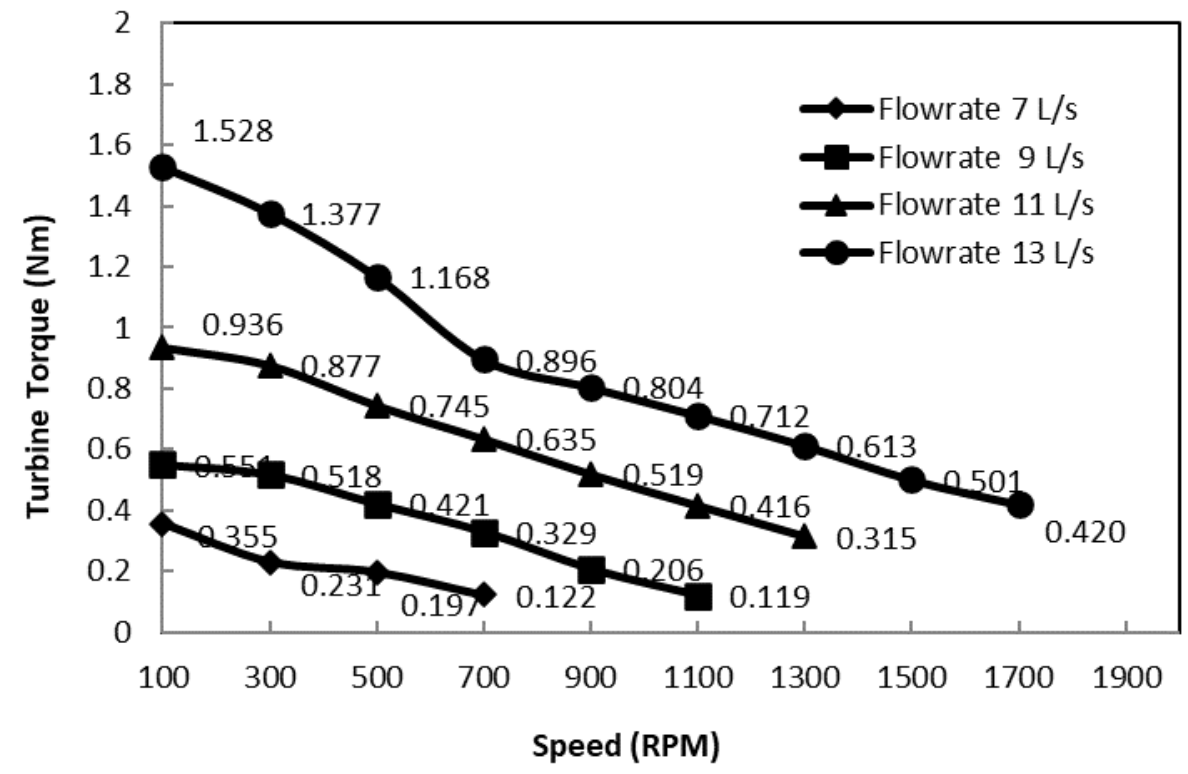

Fig. 6. Turbine torsion performance with speed variation

Figure 7 shows the effect of turbine speed on the propeller turbine power at each flowrate variation. Speed characteristics of the shaft power every varied inflow rates differently, the flowrate of 7 to $13 \mathrm{~L} / \mathrm{s}$ each successive optimum power can be produced at a speed of 500, 700, 900, and 1300 RPM. Figure 8 shows the characteristics of the velocity of water at $7 \mathrm{~L} / \mathrm{s}$ discharge, the color contour of the rotation speed of $100 \mathrm{rpm}$ after passing through the turbine in Figure 8a shows that the speed tends to be higher than at $500 \mathrm{rpm}$ (Figure 8b), this shows that at $500 \mathrm{rpm}$ the turbine converts more energy from of the water flow compared at $100 \mathrm{rpm}$.

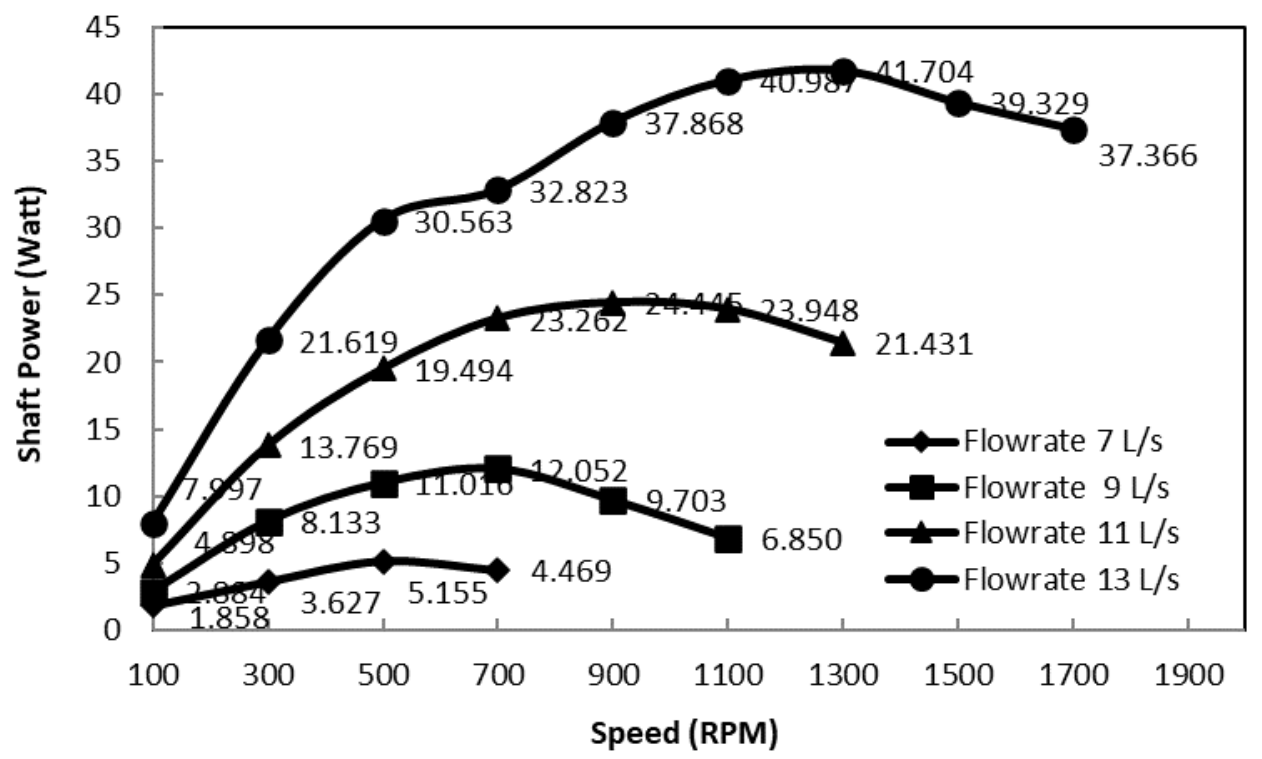

Fig. 7. Turbine shaft power performance with speed variation 


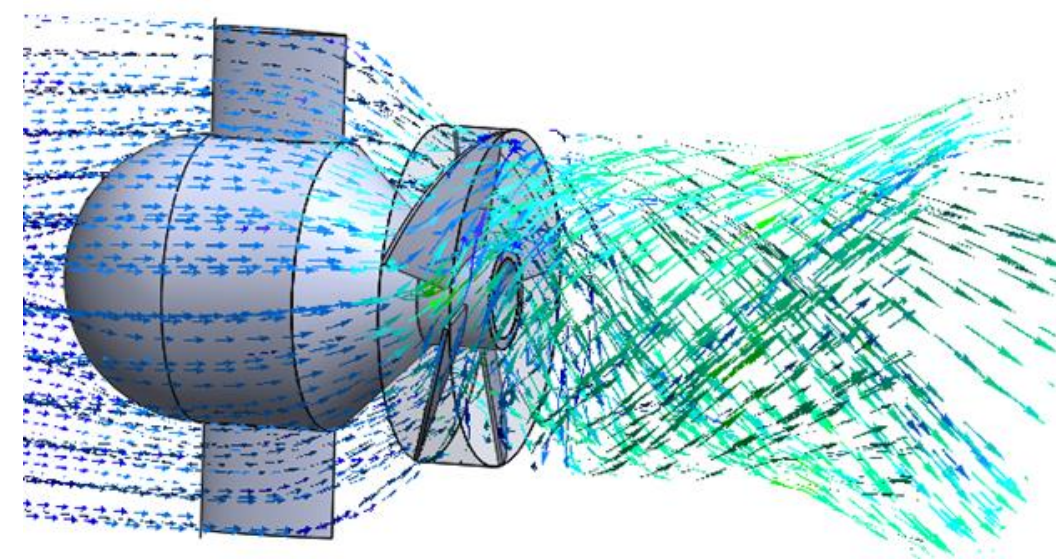

(a)

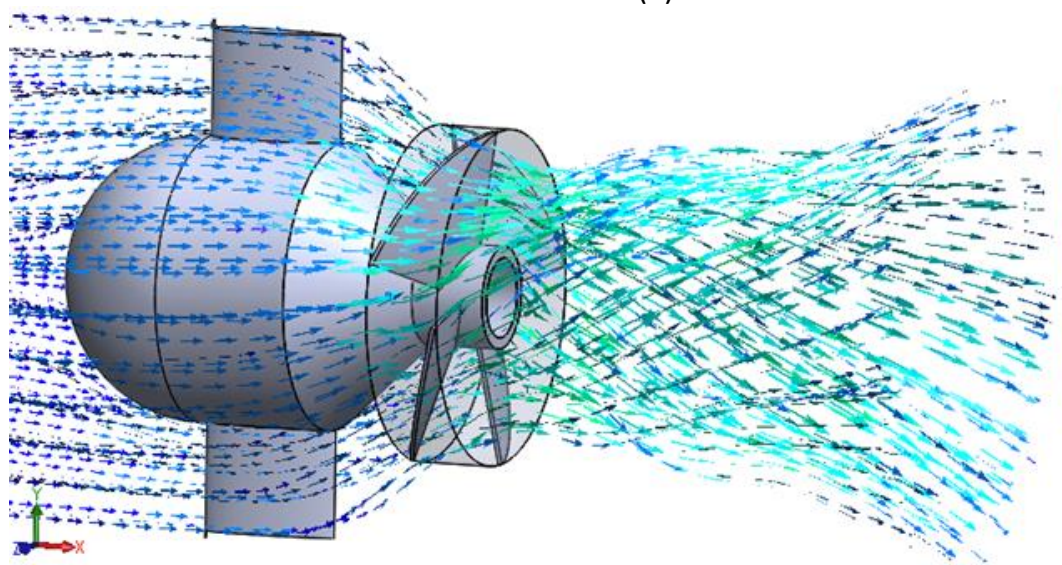

(b)

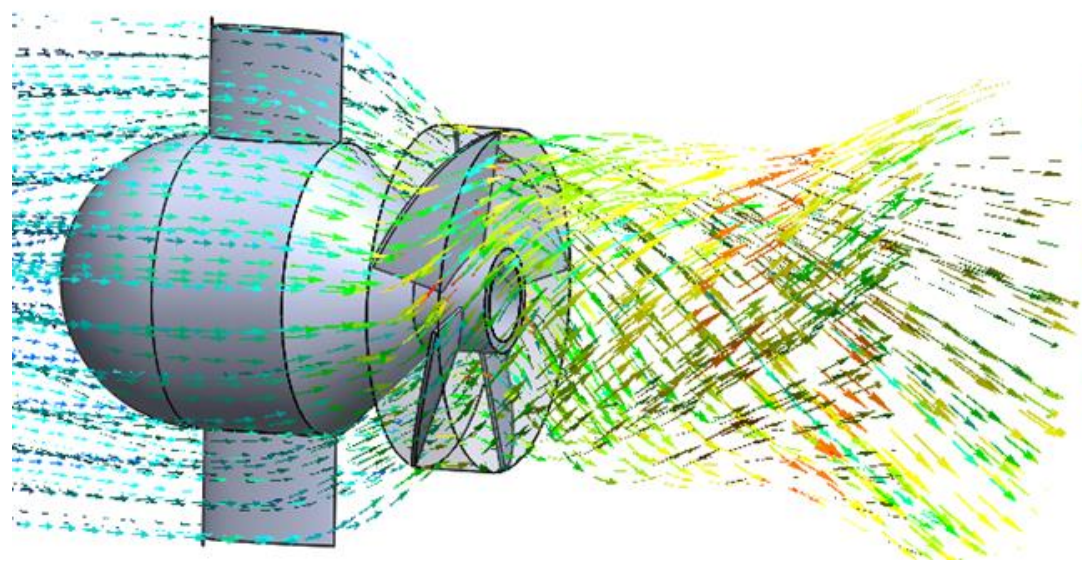

(c)
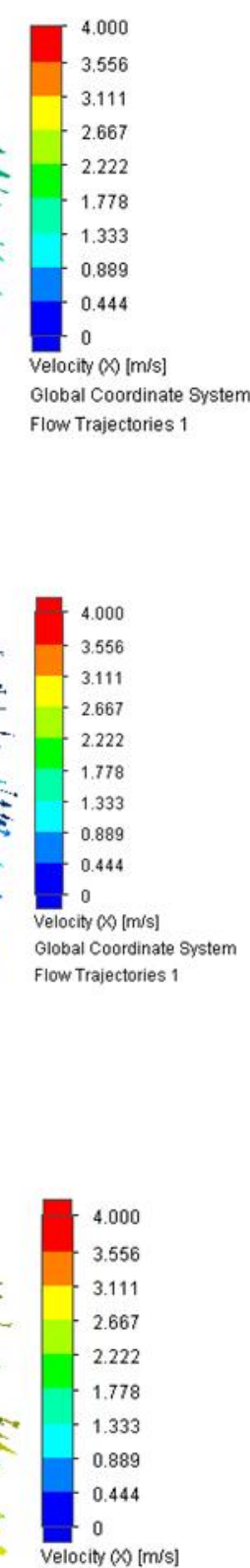

Global Coordinate System

Flow Trajectories 1

Fig. 8. Contour colour of water velocity (a) at $7 \mathrm{~L} / \mathrm{s}$ and $100 \mathrm{rpm}$ (b) at $7 \mathrm{~L} / \mathrm{s}$ dan 500 $\mathrm{rpm}$, and (c) at $13 \mathrm{~L} / \mathrm{s}$ and $500 \mathrm{rpm}$

Figure 6 and 7 show that the rises water flowrate value, the torque and the shaft power value or the propeller turbine performance rises too. Basically, the formula is that the discharge value is always directly proportional to water power or available power [1], so that the higher the water flowrate value, the available power increases and has the potential to increase turbine performance. Using other basic formulas in reference [17] the value of water velocity directly affects the available power. Figure $8 \mathrm{c}$ shows the color contour of the water velocity at flowrate $13 \mathrm{~L} / \mathrm{s}$ and $500 \mathrm{rpm}$ before entering the turbine area faster than at a discharge of $7 \mathrm{~L} / \mathrm{s}$ at the same speed, this shows that the 
higher the discharge value, the water velocity also increases and has the potential increase turbine performance.

The pressure contour on the turbine surface in static simulations can analyze the water power that can be converted into torque [11, 12]and shaft power. Figure 9 shows the turbine surface pressure contour from the simulation results of this study at a turbine speed of $500 \mathrm{rpm}$. Figure 9(a) and 9 (b) show the pressure contours at a flow rate of $7 \mathrm{~L} / \mathrm{s}$ and $13 \mathrm{~L} / \mathrm{s}$, at $13 \mathrm{~L} / \mathrm{s}$ shows a higher contour pressure than at a flowrate of $7 \mathrm{~L} / \mathrm{s}$, so that it has the potential to produce a higher turbine performance. The efficiency value of the propeller turbine is shown in Figure 10 with the optimum value reaching $95.828 \%$ at flowrate and speed $13 \mathrm{~L} / \mathrm{s}$ and $1300 \mathrm{rpm}$.

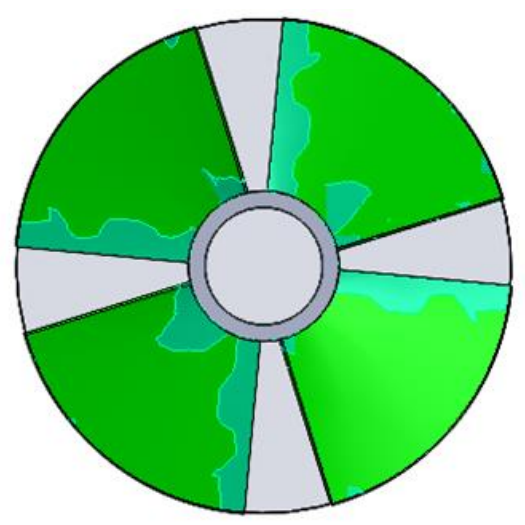

(a)
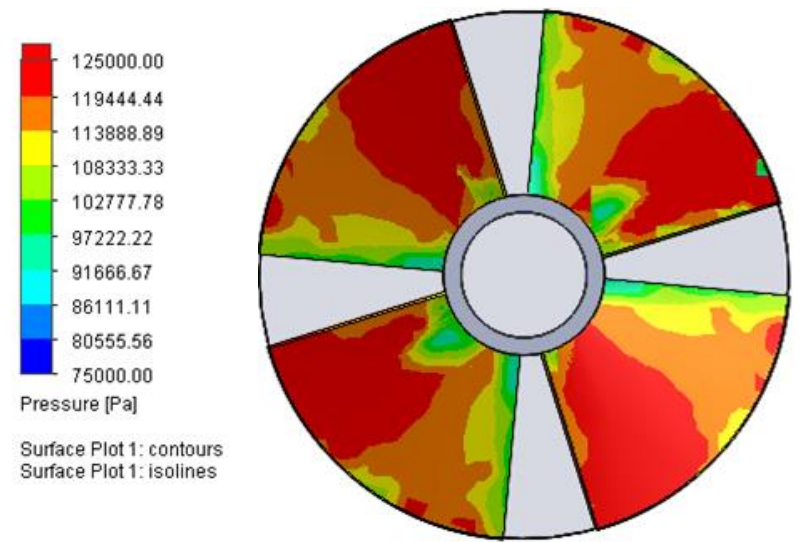

(b)

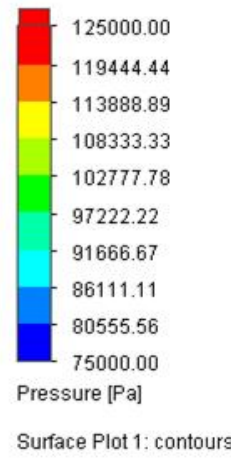

Surface Plot 1: contours

Fig. 9. Pressure of Contour colour at surface turbine (a) at $7 \mathrm{~L} / \mathrm{s}$ and $500 \mathrm{rpm}$ and (b) at $13 \mathrm{~L} / \mathrm{s}$ and $500 \mathrm{rpm}$

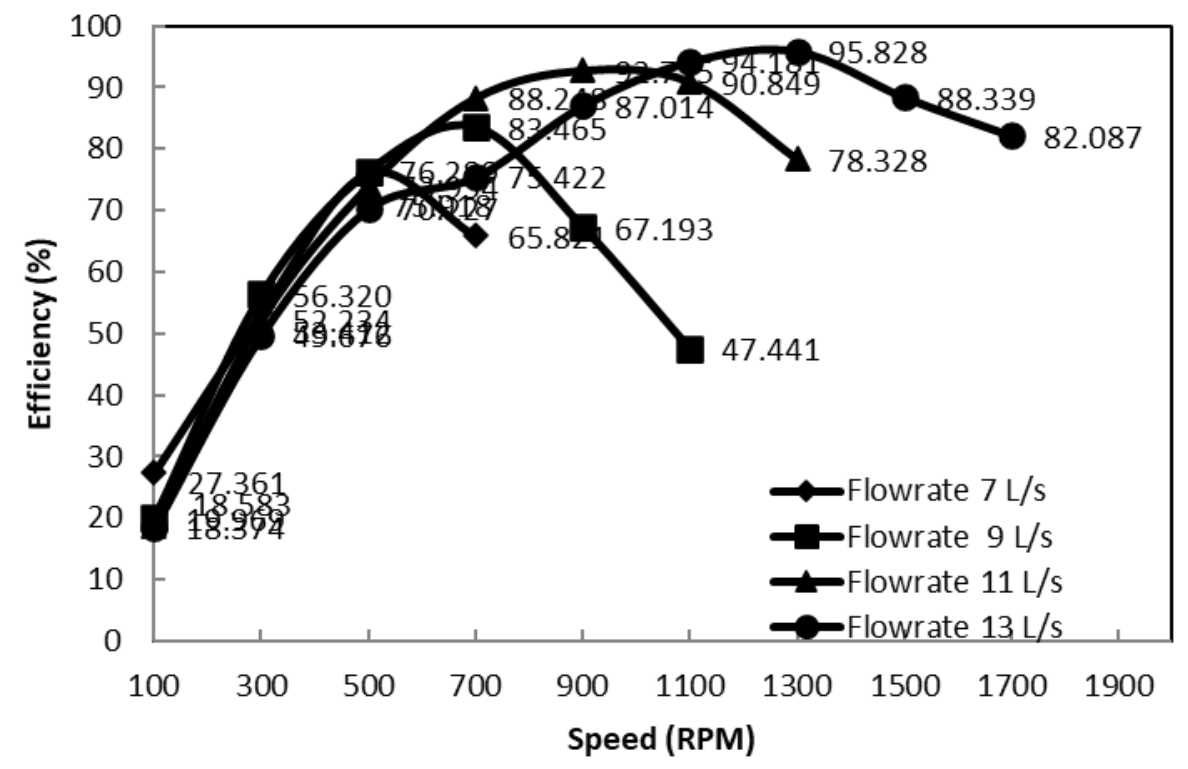

Fig. 10. Turbine efficiency with speed variation

\section{Conclusions}

In general, this study shows the effect of flow rate and speed on propeller turbine performance using numerical simulations. Based on the simulation results, the value of the turbine shaft power is always directly proportional to the value of the water flow rate, so that the higher the water discharge value the higher the resulting shaft power. This study also shows that the turbine speed affects the torque value of the turbine so that it directly affects the shaft power. The optimal shaft 
power in this study is produced at $1300 \mathrm{rpm}$ and a flow rate of $13 \mathrm{~L} / \mathrm{s}$ with an efficiency value of 95.828\%.

\section{References}

[1] Nurdin, Akhmad, Dwi Aries Himawanto, and Syamsul Hadi. "Experimental study of the effect of blade angle on pico tubular bulb turbine performance in horizontal flow." In AIP Conference Proceedings, vol. 2217, no. 1, p. 030122. AIP Publishing LLC, 2020. https://doi.org/10.1063/5.0002920

[2] Nurdin, Akhmad, and Dwi Aries Himawanto. "Kajian teoritis uji kerja turbin archimedes screw pada head rendah." Simetris: Jurnal Teknik Mesin, Elektro dan Ilmu Komputer 9, no. 2 (2018): 783-796. https://doi.org/10.24176/simet.v9i2.2340

[3] Tjahjana, Dominicus Danardono Dwi Prija, Arnold Thamrin Halomoan, Andreas Wibowo, Dwi Aries Himawanto, and Yoga Arob Wicaksono. "Wind potential assessment in urban area of Surakarta city." In AIP Conference Proceedings, vol. 1931, no. 1, p. 030070. AIP Publishing LLC, 2018. https://doi.org/10.1063/1.5024129

[4] Firdaus, Nofirman, Bambang Teguh Prasetyo, Hasnida Ab-Samat, Heri Suyanto, and Rusjdi Halim. "Wind Energy Potential on A Highrise Building: A Preliminary Study." Journal of Advanced Research in Fluid Mechanics and Thermal Sciences 88, no. 3 (2021): 20-30. https://doi.org/10.37934/arfmts.88.3.2030

[5] Qaissi, Khaoula, Omer Elsayed, Mustapha Faqir, and Elhachmi Essadiqi. "A Validation Study of the Aerodynamic Behaviour of a Wind Turbine: Three-Dimensional Rotational Case." CFD Letters 13, no. 9 (2021): 1-12. https://doi.org/10.37934/cfdl.13.9.112

[6] Nurdin, Akhmad, and Dwi Aries Himawanto. "Review aplikasi bahan bakar biogas pada motor bakar SI (Spark Ignition)." Simetris: Jurnal Teknik Mesin, Elektro dan IImu Komputer 9, no. 2 (2018): 797-802. https://doi.org/10.24176/simet.v9i2.2341

[7] Shafie, Shafini Mohd, A. Harits Nu'man, and Nik Nurul Anis Nik Yusuf. "Biogas to Fuel Cell State of The Art: A Review." Journal of Advanced Research in Fluid Mechanics and Thermal Sciences 86, no. 1 (2021): 87-104. https://doi.org/10.37934/arfmts.86.1.87104

[8] Himawanto, Dwi Aries, Harwin Saptoadi, and Tri Agung Rohmat. "Thermogravimetric analysis and global kinetics of segregated MSW pyrolysis." Modern Applied Science 6, no. 1 (2012): 120. https://doi.org/10.5539/mas.v6n1p120

[9] Rosli, Mohd Afzanizam Mohd, Yew Wai Loon, Muhammad Zaid Nawam, Suhaimi Misha, Aiman Roslizar, Faridah Hussain, Nurfaizey Abdul Hamid, Zainal Arifin, and Safarudin Gazali Herawan. "Validation Study of Photovoltaic Thermal Nanofluid Based Coolant Using Computational Fluid Dynamics Approach." CFD Letters 13, no. 3 (2021): 5871. https://doi.org/10.37934/cfdl.13.3.5871

[10] Nurdin, Akhmad, and Dwi Aries Himawanto. "Studi numerik kekuatan material transmisi roda gigi pico hydro." Jurnal Teknik Mesin Indonesia 14, no. 1 (2019): 24-29. https://doi.org/10.36289/itmi.v14i1.101

[11] Nurdin, Akhmad, and Sri Hastuti. "OPTIMALISASI DAYA OUTPUT GENERATOR PADA PICO-HYDROPOWER MENGGUNAKAN TRANSMISI RODA GIGI." Journal of Mechanical Engineering 4, no. 2 (2020): 7-14. https://doi.org/10.31002/jom.v4i2.3411

[12] Almeida Samora, Irene, Vlad Hasmatuchi, C. Münch-Alligné, Mário J. Franca, Anton Schleiss, and Helena M. Ramos. "Energy production with a tubular propeller turbine." In Proc. of the 28th IAHR symposium on Hydraulic Machinery and Systems, no. CONF. 2016.

[13] Samora, I., and V. Hasmatuchi. "Mu" nch-Alligné C., Franca MJ, Schleiss AJ, and Ramos HM (2016). Experimental characterization of a five blade tubular propeller turbine for pipe inline installation." Renewable Energy 95: 356366. https://doi.org/10.1016/i.renene.2016.04.023

[14] Chen, Jian, H. X. Yang, C. P. Liu, C. H. Lau, and M. Lo. "A novel vertical axis water turbine for power generation from water pipelines." Energy 54 (2013): 184-193. https://doi.org/10.1016/i.energy.2013.01.064

[15] Nurdin, Akhmad, Dwi Aries Himawanto, and Syamsul Hadi. "Study of the Effect of Bulb Ratio and Blade Angle on Propeller Turbine Performance in Horizontal Flow using Numerical Simulation." TEKNIK 41, no. 1: 9-13. https://doi.org/10.14710/teknik.v41i1.25328

[16] A. Nurdin, D. A. Himawanto, and S. Hadi, "THE UTILIZATION OF HORIZONTAL PIPELINE FOR A STATIC BULB TURBINE AND THE DETERMINATION OF OPTIMUM BLADE NUMBER," vol. 19, no. 2, pp. 61-68, 2020.

[17] Nurdin, A., D. A. Himawanto, and S. Hadi. "Optimasi perancangan turbin air axial aliran horisontal menggunakan analysis of variance." Dinamika Teknik Mesin 10, no. 2 (2020): 103-109.

[18] Chen, Zhenmu, Joo-Cheong Kim, Myeong-Hwan Im, and Young-Do Choi. "Analysis on the performance and internal flow of a tubular type hydro turbine for vessel cooling system." Journal of the Korean Society of Marine Engineering 38, no. 10 (2014): 1244-1250. https://doi.org/10.5916/ikosme.2014.38.10.1244 
[19] Luo, Yongyao, Zhengwei Wang, Xin Liu, Yexiang Xiao, Changkun Chen, Haoping Wang, and Jianhua Yan. "Numerical prediction of pressure pulsation for a low head bidirectional tidal bulb turbine." Energy 89 (2015): $730-738$. https://doi.org/10.1016/i.energy.2015.06.022

[20] Ramos, Helena M., Mariana Simão, and Kaloyan N. Kenov. "Low-head energy conversion: a conceptual design and laboratory investigation of a microtubular hydro propeller." International Scholarly Research Notices 2012 (2012). https://doi.org/10.5402/2012/846206

[21] Ramos, Helena M., Mariana Simão, and A. Borga. "Experiments and CFD analyses for a new reaction microhydro propeller with five blades." Journal of Energy Engineering 139, no. 2 (2013): $109-117$. https://doi.org/10.1061/(ASCE)EY.1943-7897.0000096 